ESJ Humanities

\title{
Early States and Power in the Baltic Sea Region (8th-11th Centuries): A Comparative Study
}

\author{
Nazar Rizun, MA \\ Vasyl Stefanyk National Scientific Library of Ukraine in Lviv, Ukraine
}

Doi:10.19044/esj.2021.v17n39p19

Submitted: 24 October 2021

Accepted: 24 November 2021

Published: 30 November 2021
Copyright 2021 Author(s)

Under Creative Commons BY-NC-ND

4.0 OPEN ACCESS

Cite As:

Rizun N. (2021). Early States and Power in the Baltic Sea Region (8th-11th Centuries):

A Comparative Study. European Scientific Journal, ESJ, 17 (39), 19.

https://doi.org/10.19044/esj.2021.v17n39p19

\begin{abstract}
The aim of the article is to trace the emergence and the development of the early states of the Scandinavians, the Polabian and the Pomeranian Slavs and to investigate their main power centers. The author relies on previous research, uses theoretical achievements of historical anthropology and combines them with comparative methodology to study both archaeological and written sources. This approach allows to establish distinct political typologies in the region, namely various types of chiefdoms and principalities. The paper illuminates similar and mostly simultaneous trajectories of the evolution of those polities, emphasizes the role of central places in the respective political systems and in the governing mechanisms. During the late 8th - the early 11th centuries there had existed complex chiefdoms and chiefdom confederacies, which slowly declined towards the end of the period.
\end{abstract}

Keywords: Scandinavians, Slavs, chiefdom, principality, central place

\section{Introduction}

The Scandinavians inhabited the northern shore of the Baltic Sea, while the Polabian and the Pomeranian Slavs - "the westernmost group of the Western Slavs" (Zaroff, 2007, p. 3) - the southern one. Both engaged in fish catching and exploration of the sea routes. Climate in these lands is similar, but not identical. In Norway and Sweden the natural environment is harsher than in Polabia and Pomerania. Due to the subarctic type of climate, especially unwelcoming are the northernmost parts of Scandinavia, making it nearly 
impossible to cultivate the land. On the territories of the Baltic Slavs, writes Mykola Rud', "the large number of rivers, lakes as well as the sea, had helped to develop fishing industry and rich in the amount of animals forests had led to profitable hunting" (Rud', 2011, p. 31).

For the inhabitants of Norway and Sweden economically the most important was the production of cattle. Individual farms, which sometimes unified into small settlements, provided the basis of the local economy. Cities rarely emerged in the whole region. Among the largest and the most prominent were Kaupang and Nidaros in Norway, Hedeby in Denmark, Uppsala and Birka in Sweden, Meklenburg and Radogosc in Polabia, Pyrzycze and Szczecyn in Pomeraina. Their amount had started to rise dramatically as late as the 11 th - the early 12 th centuries.

On the territories inhabited by the Polabian and the Pomeranian Slavs people were able to produce food not only for consumption, but also for trade. The economic rise had also happened here due to the fact that Polabia and Pomerania are situated on the crossroads of various continental and sea routes. As a result, in the lands of the Baltic Slavs urbanization was more prevalent than in Scandinavia. Their cities were larger in size and in number of inhabitants. Such urban centers emerged on the Baltic seashores and alongside continental and river routes (Shchodra, 2019, pp. 10, 12-13).

In the "Slavic chronicle" Helmold of Bossau describes the whole region: "The Danes and the Sveons, known as the Normans, control its northern shore and all the surrounding islands, and the Slavic people inhabit the southern shore" (Helmoldi, 1937, p. 5). Adam of Bremen presents similar picture and situates the inhabitants of the region: "In the north live the Normans, very wild tribes, in the east - the Obodrites, and in the West - the Frizes" (Magistri Adam Bremensis, 1917, p. 7). The chronicler depicts the whole region in such a way: "The one shore of this [Baltic. - N. R.] sea is under the control of the Slavs, and the other - of the Swedes" (Magistri Adam Bremensis, 1917, p. 242). Adam of Bremen also writes: "In this bay there are many islands, all of them under the control of the Danes and the Swedes, and some - of the Slavs" (Magistri Adam Bremensis, 1917, p. 242).

The article outlines the state formation processes in this region from the late 8 th to the early 11 th century and explores the role of major power centers in the political systems of the Scandinavians, the Polabian and the Pomeranian Slavs. In other words, the study explains how the early states emerged, how they had been governed, and highlights both similarities and differences between Scandinavian and Slavic societies.

\section{Theoretical framework}

"The term "chiefdom", writes Michał Tymowski, "was introduced into political anthropology in 1955 by Kalervo Oberg" (2009, p. 5). During the 
second half of the century the concept has been accepted and further developed by a number of scholars, in particular Timothy Earle (1993, 1997), Elman Service (1971, 1975), Robert Carneiro (1970, 1981), Peter Skalník (2004). A few historians, among them such medievalists as Karol Modzelewski (2004, pp. 347-401) and Michał Kara (2012, p. 869), demonstrated the usefulness of this theory for the studies on the early medieval Slavic and Germanic societies.

T. Earle defines chiefdom as a political formation that unites several thousand people. Such societies emerged from smaller communities and sometimes transformed into states (1993, p. 1). K. Modzelewski understands chiefdom as a territorial and political organization, where power is in the hands of assemblies (2004, pp. 358-359). According to M. Kara, under their rule chiefs performed military, judicial, and religious functions (2012, pp. 875876). Also, in a chiefdom rulers redistributed wealth, did not have a support of any formal administration, and were under the rule of communities and other chiefs (Tymowski, 2009, p. 6).

Leontii Voitovych thinks that chiefdom is "a stable structure, which has centralized governance and hereditary hierarchy of rulers and aristocracy, but does not have a formal administrative framework yet" (2010, p. 35). The article, while taking into account all the presented opinions, mostly relies on this definition of chiefdom.

According to the scholars, three main types of chiefdoms are simple, mixed, and complex or consolidated (Voitovych, 2011, p. 8). The last one represents the final step before the emergence of a state (Mykhailyna, 2010, pp. 261-265).

Theoretical categories of political anthropology help to establish the existence of respective polities in the lands of the Scandinavians, the Polabian and the Pomeranian Slavs in the early medieval period. The sources allow to trace a number of political organizations that are hierarchical and already have dynasties, but at the same time lack strong central power and administrative framework as well as cover relatively small territories. The ability of chiefs to rule over the inhabitants of such pre-state societies are limited by those members of communities, who regularly participate in assemblies. Also, of high importance is the existence of special administrative and sacral sites or settlements - the centers of chiefdoms.

\section{Research methods}

Methodologically the study of Scandinavian and Slavic early states and their major power centers relies on the achievements of historical anthropology. The research borrows a few important concepts from the works of anthropologists and takes into account their successful application by historians, foremost medievalists. This approach to the analysis of the archaeological and written sources allows to identify and typologize a variety 
of chiefdoms, larger chiefdom organizations as well as principalities in the lands inhabited by the Scandinavians, the Polabian and the Pomeranian Slavs. Additionally, the study applies a variety of comparative methods, foremost historical-typological method. Accordingly, the comparison is done as follows. First, the pre-state political organizations and early states are presented and their choice is explained and substantiated. Then, the criteria of typological comparison are defined and all the necessary information is described. Finally, the study shows the differences between those organizations and polities and explains the reasons for their existence.

\section{The emergence of early states}

At different times chiefdoms had existed in all parts of the world (Tymowski 2012). The lands of the Scandinavians and the Baltic Slavs had not been an exception. Scholars divide chiefdoms into a few types and describe each of them with certain features. Over time some of these political formations united with one another, and in such a way had emerged chiefdom confederacies. According to David Gibson, "states that developed from chiefdom confederacies later had federal or feudal character, and because of that the legacy of chiefdom confederacies were kingdoms, which can be found in Germanic and Slavic regions, such as the state of Merovings and Rus', that had strong oligarchies and weak rulers" (2011, pp. 228-229).

Such societies had existed in between tribal and state periods across the lands of the Scandinavians and the Baltic Slavs. However, the early states and social organizations had not always evolved in precisely the same way. The development of the Polabian and the Pomeranian Slavs had not been simultaneous. In addition, these two cases led to different results. Vladimir Ronin and Boris Floria emphasize that in Pomerania "the process of state formation [...] had been exceedingly long. But in comparison to Polabia here [...] this process at least led to the creation of early feudal state on the local basis" (1991, p. 127).

Despite such differences in a general outline the lands of the Polabian and the Pomeranian Slavs had developed in a similar way. Many analogies also could be found in contemporary Scandinavia. The most obvious similarities exist between Sweden and Pomerania - two chiefdom confederacies (Ronin \& Floria, 1991, p. 130).

In pre-state Norway the territories of the most prominent political activity, as identified by scholars, had been Agder in the south, Rogaland in the southwest, Hordaland in the west, and Grenland in the east. Archaeological material indicates the large as well as continuous presence of elites in these places (Skre, 2014, p. 36).

Based on the analysis of written, archaeological, topographic, and other sources Frode Iversen established that during the 6th-8th centuries in 
Norway had existed 15 and in Sweden - 12 different in the size and in the number of inhabitants tribes (2020, pp. 291-292). They correspond to the enlisted regions, where the presence of elites is undeniable. It is possible to identify these political organizations as complex chiefdoms.

Archaeological sources from the time also show the functioning of courtyard sites. Some scholars interpret them as local things (Grimm \& Stylegar, 2004; Storli, 2010). Gatherings of such level were the centers of simple chiefdoms. The idea that courtyard sites functioned as things has a lot of supporters, but is not certain (Brink et al., 2011). In addition, their existence is proven only in Norway. Such gatherings mostly disappeared by the end of the 8th century (Iversen, 2020, p. 297).

During the next stage of political evolution Scandinavia had formed a number of law areas. From the beginning of the 9th to the end of the 11th century on the former territories of the tribes in Norway had emerged 5 and in Sweden - 12 regions, each with its own laws (Iversen, 2020, pp. 291-292). Such consolidation resulted in the formation of polities of territorial type, which indicates the transition from the large tribes to the early states.

The source known as "Bavarian geographer" (the late 8th or the 9th century) describes the number of regions and settlements of various Slavic tribes, the Obodrites and the Lutici in particular (Voitovych, 2009, p. 12). The evidence concerning these tribes is reliable, because they had lived close to the borders of the Frankish empire (Voitovych, 2009, p. 15). The text says: "Those that are the closest to the Danish borders, are called the Nortabtrezi, their region, which has 53 towns, is ruled by their chiefs" (Voitovych, 2009, p. 13). The source also says: "The Uilci, who have 95 towns and 4 regions' ' (Voitovych, 2009, p. 13).

Historians have no doubts that the Nortabtrezi are the Obodrites and the Uilci - the Lutici. Rostyslav Vatseba thinks that civitates of the "Bavarian geographer" correspond to simple chiefdoms and regiones - to complex chiefdoms (2019, p. 142). This allows us to assume that 15 Norwegian and 12 Swedish tribes are quite similar to the regions of the Lutici. Such a conclusion is reasonable due to the similarities in social development of the Scandinavians and the Baltic Slavs during this period of time and comparable size of territories as well as the number of inhabitants.

The "Ynglinga saga", which belongs to a collection of sagas entitled "Heimskringla", describes the first rulers of Sweden and Norway. The dynasty ruled in the province of Uppland and then - in Vestfold (Snorri Sturluson, 1911, pp. 31-32). Both regions were the main places of the state formation processes in Scandinavia. However, it is almost impossible to establish if the version about the common ancestry of Scandinavian rulers is true. Snorri Sturluson, the author of the saga, lived at the end of the 12th - at the beginning of the 13th century, and so did not have access to reliable oral or written 
evidence about the beginnings of Swedish and Norwegian history. His description of the Ynglinga dynasty contains a lot of legendary material. Nevertheless, Dagfinn Skre assumes that the general outline of the story about the first Scandinavian konungs is trustworthy (Skre, 2007, p. 417).

From the legendary times to the Viking Age military chiefs with limited power ruled over Uppland and Vestfold. They controlled only small territories and were not always able to enforce their rule. Such chiefs achieved their goals with help of retinues and based on their authority, which increased due to military victories abroad and participation in religious rituals (Snorri Sturluson, 1911, p. 10-35).

One of the first rulers in Uppland, who resided in Uppsala, was Dómaldi. It is hard to tell society of what time depicts the saga, but most likely it covers the period from the prehistoric times until the end of the 8th century. Interestingly, the people accused him in lack of food, and so his retinue sacrificed him (Snorri Sturluson, 1911, pp. 12-13). The attitude towards the chief was similar during the Iron Age and the Viking Age. In the story he appears as one of the warriors, who has only slightly more authority, power, status, and influence, than the others. However, there is no dramatic difference between Dómaldi, chiefs of lower ranks, and warriors. At this time the power of a ruler was not completely differentiated from the rest of society. People often elected as well as removed a chief. The next ruler of Uppsala was Dómar, Dómaldi's son. And after him Dyggvi and Dag controlled the region. The saga depicts Dag as well as his successor Agni as military chiefs, that participated in many conquests (Snorri Sturluson, 1911, pp. 13-15).

The "Ynglinga saga" and the poem "Ynglingatal" also describe rulers of Vestfold. They name five konungs. The first one from the Ynglinga dynasty in Norway was Eysteinn. Simultaneously with him there were other konungs, Sigtryggs and Skjold. Halfdan was the successor of Eysteinn, and afterwards Gudrod ruled over Vestfold. The last chiefs from the dynasty in the province were Olaf and Rognvald (Snorri Sturluson, 1911, pp. 32-35).

For the first time the Lutici (Wilze, Wiltzorum) and the Obodrites (Abotriti) appear in the "The Royal Frankish Annals" (789) (Annales regni Francorum, 1895, pp. 84-85). The evidence about their social organization is very scarce. At the end of the 8th century Dragowit (Dragawiti) was the ruler of the Lutici. The chronicle also mentions a few lesser chiefs. According to the Frankish author the Lutici were populous tribes (Annales regni Francorum, 1895, pp. 85-86). The information indicates their strong political influence in the region.

There is not much more data about the society of the Obodrites. Vitcin (Witzinum) was one of their rulers (Annales regni Francorum, 1895, p. 97). In 798 they had been the allies of the Franks and fought on their side: "The Obodrites had always supported the Franks" (Annales regni Francorum, 1895, 
p. 105). And in 799 Frankish empire had contacts with the Lutici and the Obodrites (Annales regni Francorum, 1895, p. 107). Finally, in 804 the Franks transferred to the Obodrites a few administrative units (pagi) beyond the river Elba (Annales regni Francorum, 1895, p. 118).

The union of the Obodrites emerged somewhere during the 7th-8th centuries (Salivon, 1981, p. 132). R. Vatseba writes that their principality in the 8th-10th centuries had not been monolithic, and a few princes ruled over it (2019, p. 197). From the economic point of view war was extremely important for the Obodrites, allowed their chiefs to maintain a retinue. According to R. Vatseba, "at the end of the 8th - the first half of the 9th century the center of the state formation transformations of the Obodrites had been in the Stargrad" (2019, p. 206).

Most likely their principality was not completely centralized, and a ruler did not possess a mechanism that would allow to easily enforce various decisions and to control the entire territory. The sources describe the rulers of the Obodrites in the early period of their history as military chiefs. As well as the Scandinavian leaders, they fought against their neighbors, foremost the Franks and the Saxes.

In the lands of the Pomeranian Slavs during the 10th - the early 11th centuries settlements of the tribal period had declined (at least 171 such places are known) and the new centers were founded. Approximately 60 percent of such defensive structures never recovered (Łosiński, 1982, p. 115). Władysław Łosiński writes that "on the other territories of Pomerania remained, it seems, forms of tribal organization. This is necessary to consider in the depth of the Pomeranian lands [...]. Many regions had retained a structure of small administrative units, later replaced by larger territorial politics" (1982, p. 121).

Felix Bierman argues that the organization of the early Slavs was embodied "in the form of very small units, in the tribal period in the form of chieftain' residences in forts, but also on the level of large political formations - firstly in the form of complex tribal chiefdom organizations" (2012, p. 426). In Scandinavia after the emergence of territorial organization tribal communities also had not disappeared without a trace (Gurevich, 2009, p. 451).

Chiefdoms of various types also existed on the territories with strong presence of elites in Uppland and Södermanland, two provinces on the shores of lake Mälaren, a birthplace of Swedish state. The tribes of the Svear and the Gotar, which later united under one ruler, inhabited these lands. The towns of Old Uppsala, Birka, and Sigtuna were the political and economic centers of Uppland. The water routes of lake Mälaren were quite important, inasmuch as they led to the integration of various parts of Sweden, intensified trade (Sanmark, 2009, p. 206). 
Sweden was composed of western and eastern Hautland, Vormland, Markir, Södermanland, Tjundaland, Atundaland, and Sjaland. In each province a thing meeting and particular law. The most important law was the one that was in use in Uppland (Snorri Sturluson, 1911, pp. 237-238). Snorri depicts the intermediate stage of evolution of the Swedish legal system, which differed from one part of the country to another. Regional diversity of the legal norms had been preserved until the middle of the 11th century. Contemporary state was not fully centralized yet. Konungs of Sweden were not in complete control of the lands around Uppland, not to mention more distant territories.

Political consolidation had been ongoing in Sweden from the late Iron Age (6th-8th centuries) to the end of the Viking Age (the middle of the 11th century). This had also affected the economy. Johan Runer thinks that at first the country acquired the goods during the contacts with the other societies and later - from taxation. The scholar emphasizes the change from the economy oriented towards war to the economic relations oriented towards the effectiveness of local production. The historian also states that the confederation of the Swedish tribes was composed of separate lands with their own laws. In his opinion, such social organization existed in Sweden approximately from the 9th to the middle of the 11th century (Runer, 2016, p. 165).

\section{The role of central places}

A variety of chiefdoms (Voitovych, 2011, p. 9) developed from egalitarian organizations of the previous period and later formed the basis of unified Norway and Sweden as well as the foundation of early states in Polabia and Pomerania. In all the regions those processes had been quite slow. Piotr Boron argues that the development of Slavic societies from tribal to state organizations had been long (Boroń, 1999, p. 9). Even longer such processes had been in the lands of the Polabian and the Pomeranian Slavs (Ronin \& Floria, 1991, p. 116).

Aron Gurevich emphasizes similar traits in the evolution of the Scandinavian societies and says: "The first thing, that becomes apparent during the investigation of medieval history of Scandinavian countries and, in particular, of Norway, is the slowness of their socio-economic development" (2009, p. 371). The medievalist explains this feature of the Viking Age Scandinavia as rooted in the "unique stability of tribal forms of society", among them, enlists military democracy (Gurevich, 2009, p. 374).

Przemysław Urbańczyk explains the reasons for such a slow transformation somewhat differently, particularly notes the complexity of the consolidation processes in ancient and medieval societies. In his opinion, "ambitious leaders and their close supporters" (Urbańczyk, 2015, p. 246) only rarely acquired and retained their own polities. P. Urbańczyk outlines 
economic, political, military, and religious levels of integration. From the first to the last they covered larger and larger territory (social and geographic space in the terminology of P. Urbańczyk) (2015, p. 246).

In most cases the economy functioned as a local market. Political networks of control connected slightly larger territories, but were weak due to undeveloped means of communication, often declined. Military actions could reach even further (approximately one hundred kilometers), but allowed to establish only temporary control based on force. Belief systems covered the largest territories, however their power to organize and mobilize was not strong enough without additional institutional support (Urbańczyk, 2015, p. 246).

A. Gurevich argues that the key reason for the slow evolution of social, political, economic, and other institutes in medieval Norway lays in the features of social organization. P. Urbańczyk explains that longevity of tribal and early state periods in the history of the Polabian Slavs was the result of undeveloped means of control.

In early medieval Scandinavia, Polabia, and Pomerania representatives of central power were not able to fully enforce their rule (HedenstiernaJonson, 2009, p. 43). Local elites had not always obeyed a ruler and attempted to maintain their independence. Aristocracy, chiefs, and other social stratas, that controlled local and regional communities, functioned as separate political entities. In Scandinavian and Slavic societies central places (Skre, 2017; Moździoch, 1999; Gerritsen \& Roymans, 2006), in particular locations of assemblies and centers of pagan cult, were the main institutes of power. They constituted a foundation of Scandinavian and Slavic social organizations and politics.

German geographer Walter Kristaller coined the phrase "central place" in the first half of the 20th century, but his definition is somewhat general, and needs clarification. Also, it is not obvious how exactly to explain this concept and how to apply it in the historical studies (Skre, 2017, p. 220). Typical for these locations are such features: "The functions of a central place have a scope beyond the needs of the inhabitants of that place and they reach out to the surrounding communities" (Skre, 2017, p. 220).

Archaeologists are the scholars that most often apply the concept, investigate hierarchy of central places, inasmuch as some of them often had been under the influence of the other. Stefan Brink writes: "What I am tracing are sites or small settlement structures that have had some function or significance exceeding the particular site or settlement, in other words, some kind of "power" over a wider area" (Brink, 1996, p. 237). Central places were multifunctional, often formed entire networks (Brink, 1996, p. 237).

The best known and the most studied central place in Norway is Skiringssal in the province of Viken in the western part of the country 
(Vestfold). Archaeologists discovered on this territory a thing named Pjódalyng and a cultic center and established that in the second half of the 8th - at the beginning of the 10th century there had existed a ritual hall and a husaby farm (Skre, 2017, p. 224). The location of the gathering as well as other elements of the Skiringssal had existed during the period of the 8th-10th centuries.

Researchers attempt to establish the exact territory covered by the assembly and the administrative unit under its representation (Skre, 2007, p. 386). According to Johann Fritzner Pjóðalyng functioned as a local gathering of rural community. Gustav Strom was of a different mind and argued that the assembly covered a few administrative units (Skre, 2007, p. 396). D. Skre went even further and stated that the thing represented the whole Vestfold (2007, p. 397). P. Urbańczyk disagreed with this opinion and criticized the explanation of the Norwegian archaeologist (2008).

D. Skre, whose interpretation is the most convincing, describes the regional assembly of the whole Vestfold. The territory, similar to Uppland and Södermanland in Sweden, was a birthplace of Norwegian state (Snorri Sturluson, 1911, pp. 62-63). G. Storm argued that the name of the thing comes from pre-historic times. Other scholars voiced similar opinions and assumed the ancient history of the assembly. S. Brink rejected their arguments, but agreed with the conclusion. His opinion is grounded in the newest archaeological discoveries (Skre, 2007, p. 397). D. Skre thinks that the name of the thing and the gathering as such come from pre-Christian times, however it is impossible to date assembly more precisely. The available evidence proves the continuous presence of people in this area. Here occurred seasonal celebrations, which played a sacral, judicial, and social role (Skre, 2007, p. 403).

D. Skre argues that near the Skiringssal were located burials of first two rulers from the Ynglinga dynasty in Norway. The most important components on the territory were a harbor, a road which led to the meeting hall, the location of the thing, and a sacred lake. The name of the whole complex comes from the meeting hall (Skre, 2007, p. 440).

The main place of the state formation in Sweden was a central place in Uppsala, which had not lost a key role and a strong influence in the region from the Iron Age to the Middle Ages. During the Viking Age the place already have had a long history (Ljungkvist \& Frölund, 2015, p. 3). Historians argue that Uppsala was founded in the 6th or at the end of the 5th century. Scholars also indicate the beginning of the 7th century as a possible time of the founding of the complex (Ljungkvist \& Frölund, 2015, p. 5). Contemporary findings prove such view. The richest archaeological material comes from the late 6 th - the 9 th centuries. It is possible to trace the existence 
of hierarchic society from the beginning of this period (Ljungkvist \& Frölund, 2015, p. 6).

Archaeological evidence suggests that from the 6th to the 11th century Uppsala had been a place where elite of Uppland had resided. As well as a name of the central place of Vestfold - Skiringssal - Swedish name Uppsala contains part sala, which means meeting hall. One of them was built at the beginning of the 7th century and another - in the middle of the 8th century. The second one had been in continuous use until the late 9th or the early 10th century (Skre, 2007, p. 424). The first one had probably existed until the same time (Skre, 2007, p. 424).

According to the "Chronicle of Thietmar of Merseburg", the lands of the Lutici tribes were divided into separate administrative units (regiones). A city of Radogosc was the capital of their early state - chiefdom confederacy. The settlement functioned not only as a political, but also as a religious center. Its inhabitants performed a ritual when they left for a war and payed there a tribute after a victory (Thietmari Merseburgensis, 1889, p. 148). In its political influence Radogosc was similar to the central places of Vestfold and Uppland. In all three regions assemblies occurred on a regular basis. They played a key role in the early states of the Scandinavians and the Slavs, functioned as integral parts of respective governing mechanisms.

\section{Conclusion}

During the late 8th - the early 11th centuries the Scandinavians, the Polabian and the Pomeranian Slavs went through similar stages of social and political evolution. The archaeological and written sources indicate consolidation and integration of tribal polities - the first step of state formation. The historiography emphasizes the slow character of this evolution. At the end of the 10th century the processes had ended neither in Norway and Sweden nor in Polabia and Pomerania. Social organization in the region remained archaic for a long time.

Among all the territories on the northern and the southern shores of the Baltic Sea Norwegian lands first unified into one state. This happened at the beginning of the 11th century during the rule of Olav Tryggvason and Olav the Saint, or even slightly later. At that time consolidation in Sweden was much less prominent, Svea and Gots had not created unified political formation yet. Swedish social organization of the period could be characterized as a confederation, represented by several complex chiefdoms.

Clear parallels are found in the lands of the Polabian and the Pomeranian Slavs. The Lutici, the Obodrites, the Szczecincy, and the Prissani tribes had similar systems of governance. The first comprised a union of four large tribes. The early state of the second was a formation of the Obodrites, the Polabians, and the Vagres. A slightly different political system functioned 
in Pomerania, than in Polabia. Here newly found cities, important centers of international trade, played a much larger role, each of them independent.

Early Scandinavian and Slavic states had emerged in a similar way during the unification of complex chiefdoms into one entity. Usually, this occurred on the territories with a strong presence of elites. Such processes in Norway underwent in the region of Vestfold, in Sweden - in the provinces of Uppland and Södermanland. In Polabia states emerged in the surroundings of the city of Stargrad, in the place near the city of Radogosc, and in Pomerania - around the urban centers of the Szczecincy and the Prissani.

During the tribal and the early state periods the power was embodied in central places, such as pagan worship centers, thing meetings, and elite residences. All of them formed a kind of network that functioned as arenas of social, political, economic, cultural, and other contacts. Inasmuch as there were no developed governing mechanisms, these places allowed people and rulers to communicate. This occurred at assemblies, political events of significant importance, which played an organizational role in the life of communities. The early states of the Scandinavians and the Slavs had been under the rule of power systems, which allowed to establish only weak and unstable control and to cover relatively small territories.

\section{References:}

1. Annales regni Francorum. (1895). In MGH SRG separatim editi, vol. 6. Hannoverae: Impensis Bibliopolii Hahniani.

2. Biermann, F. (2012). Land, Elite and Exploitation in Early Medieval Western Slavic territory. Revue Belge de Philologie et d'Histoire, 90, 413-428.

3. Boron, P. (1999). "Universa populi multido". Problem uczestnictwa w słowiańskich wiecach plemiennych. Średniowiecze polskie $i$ powszechne, 1, 9-21.

4. Brink, S. (1996). Political and Social Structures in Early Scandinavia I. A Settlement-Historical Pre-Study of Central Place. Tor. Journal of Archaeology, 28, 235-281.

5. Brink, S., Grimm, O., Iversen, F., Hobæk, H., Ødegaard, M., Näsman, U., Sanmark, A., Urbańczyk, P., Vésteinsson, O., \& Storli, S. (2011). Comments on Inger Storli: 'Court Sites of Arctic Norway: Remains of Thing Sites and Representations of Political Consolidation Processes in the Northern Germanic World during the First Millennium AD?' Norwegian Archaeological Review, 44 (1), 89117.

6. Carneiro, R. (1970). A Theory of the Origin of the State. Science, 169, 733-738. 
7. Carneiro, R. (1981). The Chiefdom: Precursor of the State. In G. Jones, \& R. Kautz (Eds.), The Transition to Statehood in the New World (pp. 37-79). Cambridge: Cambridge University Press.

8. Earle, T. (Ed.). (1993). Chiefdoms: Power, Economy, and Ideology. Cambridge: Cambridge University Press.

9. Earle, T. (1997). How Chiefs Come to Power: The Political Economy in Prehistory. Stanford: Stanford University Press.

10. Gerritsen, F., \& Roymans, N. (2006). Central places and the construction of tribal identities: The case of the Late Iron Age Lower Rhine region. In C. Haselgrove (Ed.), Celtes et Gaulois, l'Archéologie face à l'Histoire, 4 (pp. 251-266). Glux-en-Glenne: Bibracte.

11. Gibson, D. (2011). Chiefdom Confederacies and State Origins. Social Evolution \& History, 10 (1), 228-229.

12. Grimm, O., \& Stylegar, F.-A. (2004). Court sites in southwest Norway. Reflection of a Roman period political organization? Norwegian Archaeological Review, 37, 111-134.

13. Gurevich, A. (2009). Izbrannye trudy: Norvezhskoe obshchestvo. Moskva: Izd-vo "Tradiciya".

14. Hedenstierna-Jonson, Ch. (2009). A Brotherhood of Feasting and Campaigning. The Success of the Northern Warrior. From Ephesos to Dalecarlia. Reflections on Body, Space and Time in Medieval and Early Modern Europe, 48, 43-56.

15. Helmoldi presbyteri Bozoviensis cronica Slavorum. Editio tertia. (1937). In MGH SRG separatim editi, vol. 32. Hannoverae: Impensis Bibliopolii Hahniani.

16. Iversen, F. (2020). Between Tribe and Kingdom - People, Land, and Law in Scandza AD 500-1350. In D. Skre (Ed.), Rulership in 1st to 14th century Scandinavia. Royal graves and sites at Avaldsnes and beyond (pp. 245-304). Berlin: De Gruyter.

17. Kara, M. (2012). Mediewistyka historyczna i archeologia średniowieczna $\mathrm{w}$ badaniach nad początkami państwa Piastów. Przykład "współpracy" historiografii i archeologii. In S. Tabaczyński, A. Marciniak, D. Cyngot, \& A. Zalewska (Eds.), Przeszłość spoteczna. Próba konceptualizacji (pp. 869-884). Poznań: Wydawnictwo Poznańskie.

18. Ljungkvist, J., \& Frölund, P. (2015). Gamla Uppsala - the emergence of a centre and a magnate complex. Journal of Archaeology and Ancient History, 16, 3-29.

19. Łosiński, W. (1982). Struktura terytorialno-polityczna Pomorza w XI stuleciu w świetle archeologii. Slavia Antiqua, 28, 113-125. 
20. Magistri Adam Bremensis. (1917). In Gesta Hammaburgensis ecclesiae pontificum. Editio tertia. MGH SRG separatim editi, vol. 2. Hannoverae, Lipsiae: Impensis Bibliopolii Hahniani.

21. Modzelewski, K. (2004). Barbarzyńska Europa. Warszawa: Iskry.

22. Moździoch, S. (1999). Miejsca centralne Polski wczesnopiastowskiej. Organizacja przestrzeni we wczesnym średniowieczu jako źródło poznania systemu społeczno-gospodarczego. In Centrum i zaplecze we wczesnośredniowiecznej Europie Środkowej (pp. 21-51). Wrocław: Wydawnictwo Werk.

23. Mykhailyna, L. (2010). Obshchynni centry v systemi poluddia litopysnykh kniazhin. Arkheolohiia $i$ davnia istoriya Ukrainy: Zb. nauk. pr., 1, 261-265.

24. Oberg, K. (1955). Types of Social Structure Among the Lowland Tribes of South and Central America. American Anthropologist, 57, 472-487.

25. Ronin, V., \& Floria, B. (1991). Hosudarstvo i obshchestvo u polabskikh i pomorskikh slavian. In Rannefeodalnye hosudarstva $i$ narodnosti (yuzhnye $i$ zapadnye slavianie VI-XII vv.) (pp. 116-137). Moskva: Nauka.

26. Rud, M. (2011). Etnokulturni protsesy na terytorii Zakhidnoho Pomoria u V-X st. Ethnic History of European Nations: Collection of scientific works, 34, 29-35.

27. Runer, J. (2016). The Husabyar in the unification process of the Swedish kingdom. In L. Christensen, T. Lemm, \& A. Pedersen (Eds.), Husebyer - status quo, open questions and perspectives (pp. 165172). Copenhagen: University Press of Southern Denmark.

28. Salivon, A. (1981). Samosoznanie obodritov (k voprosu ob obrazovaniu obodritskoi rannefeodalnoi narodnosti). In Formirovanie rannefeodalnykh slavianskikh narodnostei (pp. 130-151). Moskva: Nauka.

29. Sanmark, A. (2009). Administrative Organization and State Formation: A Case Study of Assembly Sites in Södermanland, Sweden. Medieval Archaeology, 53, 205-241.

30. Service, E. (1971). Primitive Social Organization: An Evolutionary Perspective, 2nd ed. New York: Random House.

31. Service, E. (1975). Origins of the State and Civilization. The Process of Cultural Evolution. New York: W. W. Norton \& Company.

32. Shchodra, O. (2019). Epokha slovian na baltytsi: ekonomichne pidnesennia slovianskoho Pomoria u rannomu serednovichchi. Problems of Slavonic Studies, 68, 9-28.

33. Skalník, P. (2004). Chiefdom: a Universal Political Formation? FocalEuropean Journal of Anthropology, 43, 76-98. 
34. Skre, D. (2017). Centrality and places. The central place at Skiringssal in Vestfold, Norway. In Z. Glørstad, \& K. Loftsgarden (Eds.), VikingAge Transformations. Trade, Craft and Resources in Western Scandinavia (pp. 220-225). London: Routledge.

35. Skre, D. (2014). Norðvegr - Norway: From Sailing Route to Kingdom. European Review, 22 (1), 34-44.

36. Skre, D. (Ed.). (2007). Kaupang in Skiringssal. Kaupang Excavation Project Publication Series, vol. 1. Oslo: Aarhus University Press.

37. Snorri Sturluson. (1911). Heimskringla. Nóregs Konunga Sogur. København: G. E. C. Gads Forlag.

38. Storli, I. (2010). Court sites of arctic Norway: Remains of thing sites and representations of political consolidation processes in the northern Germanic world during the first millennium AD? Norwegian Archaeological Review, 43 (2), 128-144.

39. Thietmari Merseburgensis episcopi chronicon. (1889). In $M G H S R G$, vol. 54. Hannoverae: Impensis Bibliopolii Hahniani.

40. Tymowski, M. (2009). Tribal organizations in pre-state Poland (9th and 10th centuries) in the light of anthropological theories of segmentary system and chiefdom. Acta Poloniae Historica, 99, 5-37.

41. Tymowski, M. (2012). Organizacja społeczeństwa. In S. Tabaczyński, A. Marciniak, D. Cyngot, \& A. Zalewska (Eds.), Przeszłość spoleczna. Próba konceptualizacji (pp.770-782). Poznań: Wydawnictwo Poznańskie.

42. Urbańczyk, P. (2015). Polabian Slavs and processes of political consolidation. Archaeologia Polona, 48, 245-256.

43. Urbańczyk, P. (2008). What was 'Kaupang in Skiringssal'? Comments on Dagfinn Skre (Ed.): Kaupang in Skiringssal. Kaupang Excavation Project. Publication Series, vol. 1, Aarhus 2007. Norwegian Archaeological Review, 41 (2), 176-194.

44. Vatseba, R. (2019). Ranni derzhavy druzhynnoho typu u Slovianskomu Polabi (kinets VIII - persha tretyna X st.): systema vlady $i$ yii transformatsii: Dys. kand. ist. nauk: 07.00.02. Lvivskyi natsionalnyi universytet im. Ivana Franka, Lviv.

45. Voitovych, L. (2009). "Bavarskyi Heohraf": Sproba etnolokalizatsii naselennia tsentralno-skhidnoi Yevropy IX st. Ukrainian historical journal, 5, 12-34.

46. Voitovych, L. (2010). "Bavarskyi Heohraf": Sproba lokalizatsii slovianskykh kniazivstv v IX stolitti. Średniowiecze Polskie $i$ Powszechne, 2 (6), 35-66.

47. Voitovych, L. (2011). Dyskusiia pro ranniu derzhavu. Kniazha doba: istoriia i kultura, 4, 7-16. 
November 2021 edition Vol.17, No.39

48. Zaroff, R. (2007). Politics and Priests in a Pagan Slavic Principality. Collegium Medievale, 20, 3-29. 